\title{
ARBUSCULAR MYCORRHIZA IN THE LIVING COLLECTIONS AT THE ROYAL BOTANIC GARDEN EDINBURGH
}

\author{
Christopher Walker ${ }^{1}$
}

\begin{abstract}
Most plants have mutualistic symbioses (mycorrhizas) with certain fungi that occupy their roots, the most common of which fall into the category known as arbuscular mycorrhizas (AM). Although most of the arbuscular mycorrhizal fungi (AMF) are entirely subterranean, some form spore masses or sporocarps sufficiently large to be seen with the unaided eye on the surface of the substrate. During several decades of casual observation in the research greenhouses at the Royal Botanic Garden Edinburgh (RBGE), such clumps of spores from several species of AMF have been recorded. A brief introduction to mycorrhizas, with an emphasis on AM, is provided. A list of host plants grown in botanic gardens or similar situations from which AMF have been identified is given. The possible value of AMF is discussed in relation to the 'ecosystems' that develop in mature botanic garden greenhouses. Ways of using AMF to improve the establishment or growth of plants are discussed, including a suggestion that adequate controls must always be used, particularly when using previously untested commercially available products.
\end{abstract}

\section{INTRODUCTION}

Almost all higher plants, and many liverworts, do not grow alone in nature but live in symbiosis with fungal partners. These partnerships are known as mycorrhizas (from the Greek mycos-rhizos: fungus-root), and the fungal partners are generally known as mycorrhizal fungi. In some liverworts, the fungi occupy both rhizoids and gametophyte parenchyma. There is much evidence to show that the symbiosis is mutualistic, both partners benefiting from their co-evolution with each other. For a general introduction to mycorrhizas, see the book by Smith \& Read (2008).

Although there are several different kinds of mycorrhiza (Smith \& Read 2008), including some associated specifically with orchids and others with heathland ericaceous plants (e.g. Vaccinium and Erica spp.), the two main types are ectomycorrhiza and arbuscular mycorrhizas (Fig. 1). The ectomycorrhizas are formed in a number of large woody perennials, notably the Pinaceae (pines, spruces, firs, larches), most of the Fagales (oaks, beeches) in the tropics, the dipterocarps in South-East Asia and the eucalypts in Australasia. Ectomycorrhizas are formed mainly in association with forest basidiomycete fungi, many of which are well known from their autumn woodland mushrooms, such as Boletus spp., Amanita spp., Russula spp. and the chanterelles (Cantharellus spp.) or ascomycetes (the best known of which, because of their culinary

1. Christopher Walker is a mycologist.

Address: Royal Botanic Garden Edinburgh, 20A Inverleith Row, Edinburgh EH3 5LR.

Email: C.Walker@rbge.ac.uk 


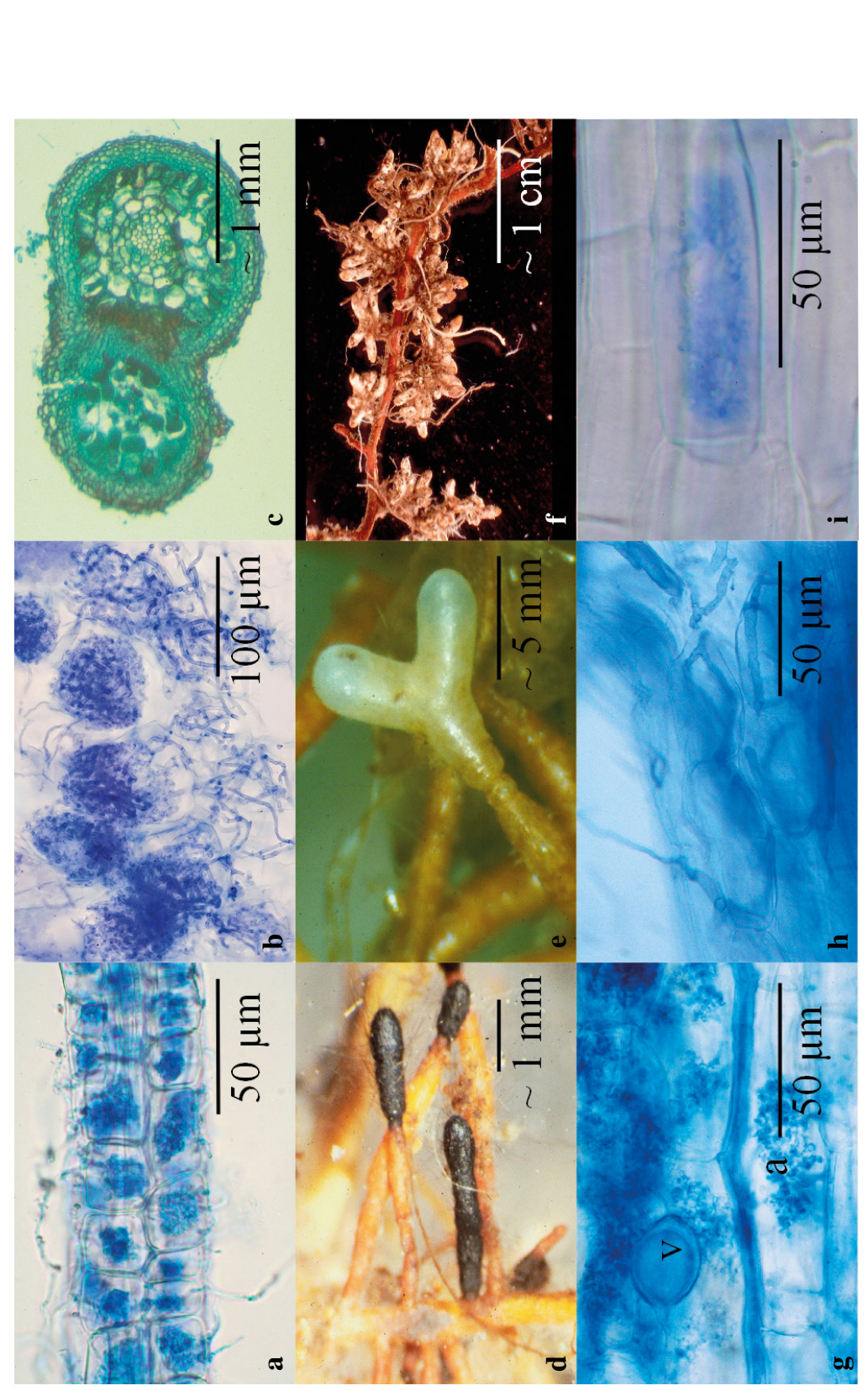

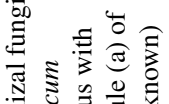

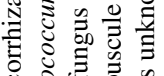

옹

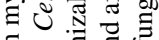

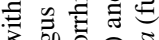

3 告造这

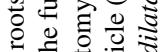

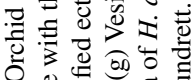

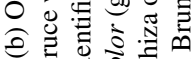

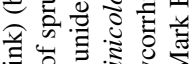

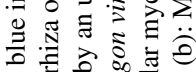

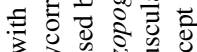

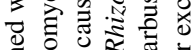

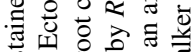

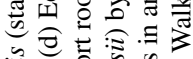

产 旅

ङ

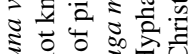

ฐ

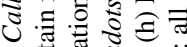

言莺

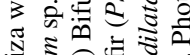

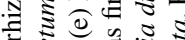

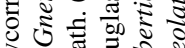

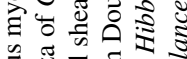

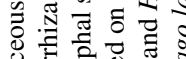

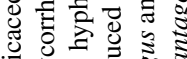

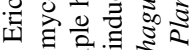

ङ

तึ

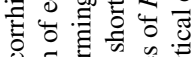

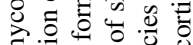

a

पे

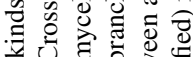

Uछ

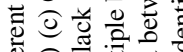

包递莺

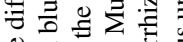

Ð 岤家家 至的寻要的 放专

-

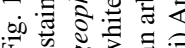


desirability, are the true truffles in the genus Tuber). At least one member of the Zygomycetes (Endogone lactiflua) forms ectomycorrhizas with conifers (Walker, 1985). This list is not exhaustive, either for the host plants or their fungal partners, but serves to show the large variety of mycorrhizal symbioses among many different groups of plants and fungi. Some hosts, such as some species of Populus, harbour more than one type of mycorrhiza (Walker \& McNabb, 1984).

\section{ARBUSCULAR MYCORRHIZA}

Ectomycorrhizas, orchidaceous mycorrhizas and ericaceous mycorrhizas are all evolutionary latecomers to the root symbiotic world. In fact the most ancient, and certainly the most common, type of mycorrhiza is the arbuscular mycorrhiza, normally abbreviated as AM (formerly also referred to as the vesicular arbuscular mycorrhiza, or VAM). Their causal fungi, presently all thought to be mycorrhizal symbionts, are even known from the Rhynie chert fossils of 407-411 million years before present: some time before roots had evolved (Dotzler et al., 2009). It is often said that more than 80 per cent of plants form this kind of mycorrhiza, though Brundrett (2009), in a detailed analysis, gives an

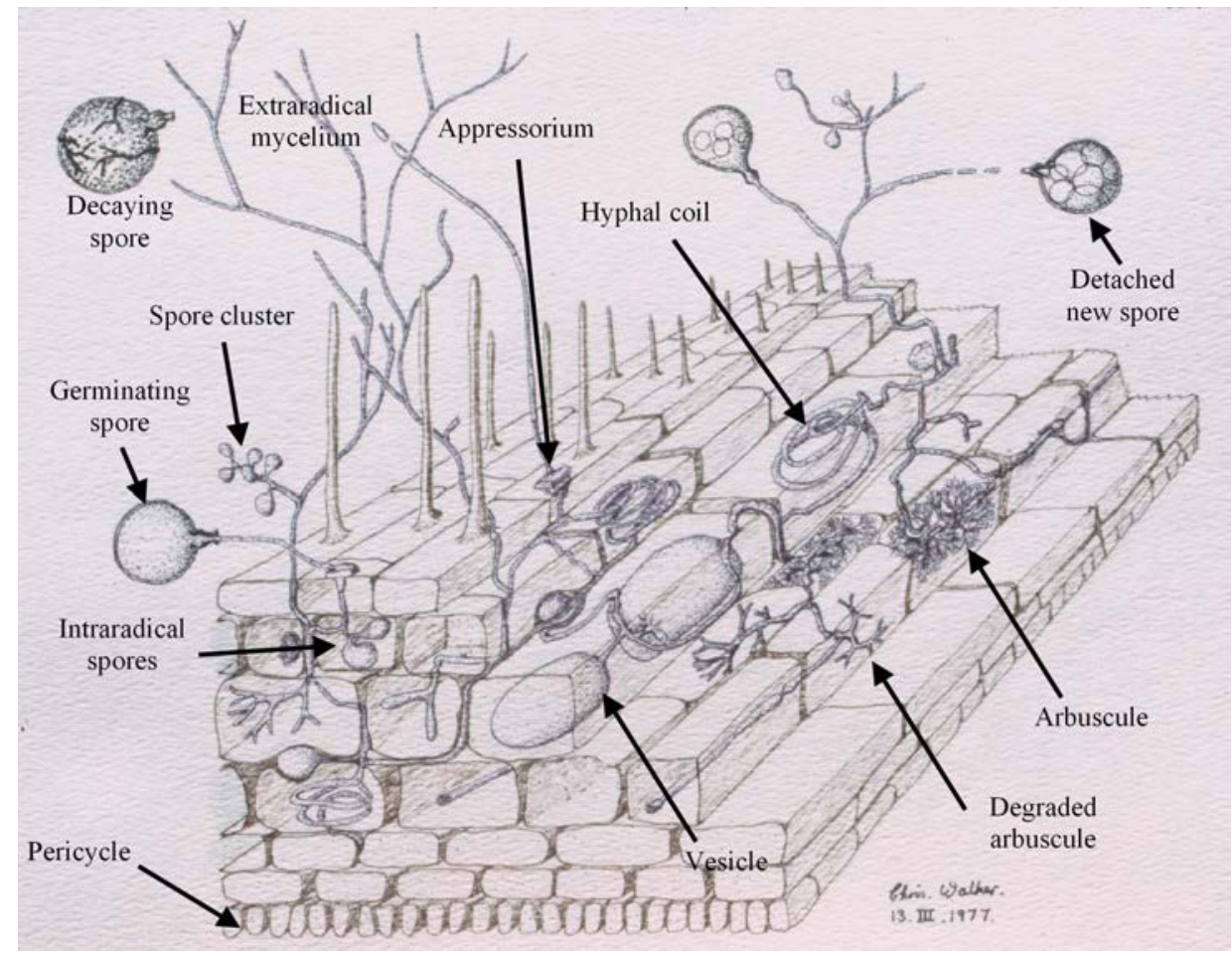

Fig. 2 Schematic of an arbuscular mycorrhiza, showing the different structures formed by the fungal partner in the outer root cells. The fungus does not penetrate the pericycle. Note the original was hand-drawn on textured paper. Drawing: C. Walker. 
estimate of just over 67 per cent that are likely to possess mycorrhizas of this type. Just under 10 per cent are non-mycorrhizal, and the remainder form other kinds of mycorrhizas. Nevertheless, it is clear that the arbuscular mycorrhizal state is more or less a norm for plants in terrestrial ecosystems.

Arbuscular mycorrhizas are named from their haustorium-like structure, the arbuscule (from the Latin for 'little bush') that occupies some of the cortical cells of the root (Fig. 2). Mycorrhiza formation is initiated from a germinating spore in the soil, when the germ tube mycelium reaches a root and forms an appressorium from which the mycelium enters the root hair or an outer cortical cell. The fungus then usually forms a coil, and then develops further by penetrating and ramifying through other cortical cells. The 'bush-like' arbuscules then develop by repeated branching, each branch being finer than its predecessor. The arbuscules invaginate the plasmalemma (cell membrane) within a cell to create a very large surface area for exchange of nutrients. In some species, sac-like vesicles are formed that act as storage organs. Spores may also be formed within the roots. The external mycelium ramifies through the soil, creating a network that may even connect to other host plants, producing what has been described as a 'wood wide web' (Helgason et al., 1998), though AMF are certainly not confined to woodlands, and are amongst the most common fungi in most soils.

\section{ARBUSCULAR MYCORRHIZAL FUNGI}

The AMF all occupy a single phylum, the Glomeromycota (Schüßler \& Walker, 2010), which currently contains 25 genera, several of which are not very well supported by

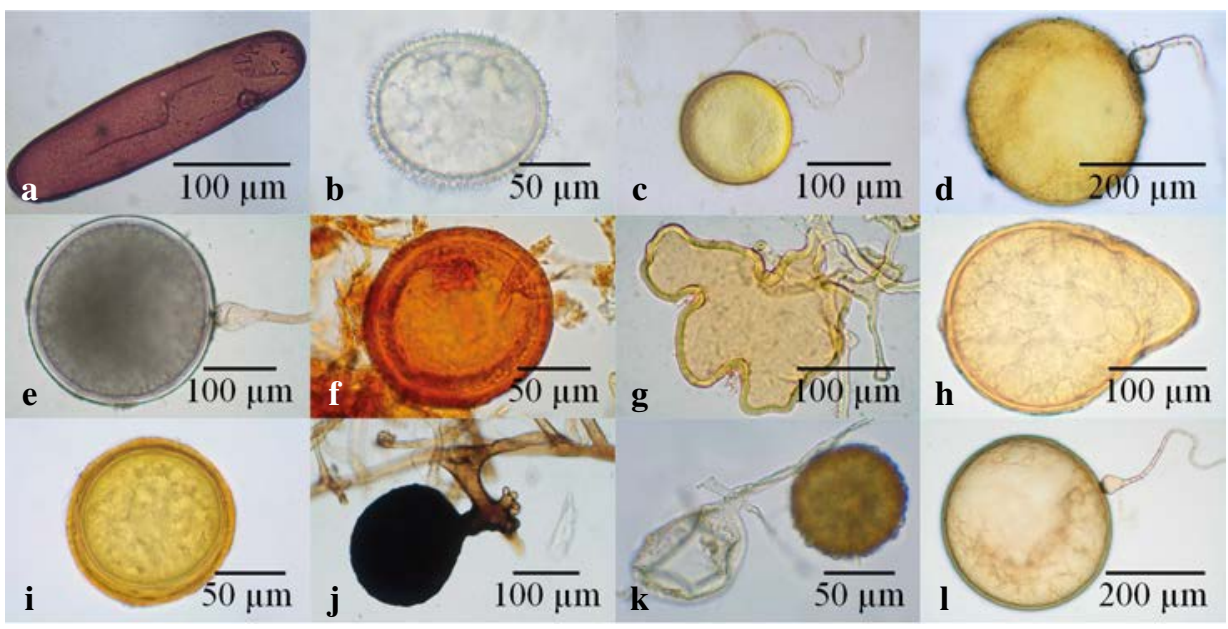

Fig. 3 A selection of arbuscular mycorrhizal fungal spores, showing some of the variation in size, shape and colour (a) Dentiscuta erythropus (see Redecker et al., 2013) (b) Pacispora scintillans (c) Claroideoglomus claroideum (d) Gigaspora gigantea (e) Cetraspora gilmorei (f) Diversispora epigaea (g) Rhizophagus irregularis (h) Diversispora sp. (i) Acaulospora sp. (j) Glomus botryoides (k) Acaulospora brasiliensis (see Krüger et al., 2011) (1) Gigaspora sp. Photos: C. Walker. 
phylogeny (Redecker et al., 2013). Apart from one species (Geosiphon pyriformis) that forms a symbiosis with a cyanobacterium (Nostoc), it is thought that all members of this ancient phylum are obligate arbuscular mycorrhizal symbionts (though many of the species were described before this relationship was known, and have yet to be proven to be mycorrhizal). The AMF form very large spores (Fig. 3), usually between 50 and 750 $\mu \mathrm{m}$ in length, but sometimes smaller, and occasionally more than $1 \mathrm{~mm}$ : exceptionally large for fungal spores, most of which are in the 2-10 $\mu$ m range. Some of these spores take on extraordinary shapes, and most are coloured: they are the main structure used for morphological identification to species. There are presently around 230 described species in the phylum, though no doubt some of these should be synonymised, but estimates based on DNA data suggest that there are many hundreds, if not thousands, of 'phylotypes', many of which might be indicative of undescribed species. However, it is very difficult to define precisely what constitutes a species in this group because they are, as far as is known, asexual and the spores are multinucleate and contain a large amount of genetic variation.

\section{HISTORICAL PERSPECTIVE ON SPECIES FROM BOTANIC GARDENS WITH SPOROCARPIC OR SPORE CLUSTERS}

One of the earliest new species of what we now know to be the Glomeromycota was from a botanic garden in Helsinki. The species Glomus versiforme was described from spores that were produced in masses associated with a potted plant (Karsten, 1884; Schüßler et al., 2011). Though this fungus probably was associated as a mycorrhizal partner with the plants, all that is known is that it was 'buried in the soil of plants', without any indication of the likely host species. Later study showed that there were two different species of AMF combined in this collection, one of which was G. versiforme; the other was formerly called G. epigaea but was recently moved into a new genus as Diversispora epigaea (Schüßler \& Walker, 2010). It should be borne in mind that it was not until 1953 that a conclusive relationship between the spores used to described glomeromycotan fungi and the arbuscular mycorrhizas they produce was established (Mosse, 1953).

Gerdemann \& Trappe (1974) reported Sclerocystis dussii and S. coremioides sporulating on the substrate surface of potted plants in the Botany Greenhouse at Oregon State University. They showed that the latter fungus was a mycorrhizal species by taking sporocarps from the surface of a pot containing Musa sp. (banana and plantain) and using them to inoculate a Zea mays (corn) plant which consequently became mycorrhizal. A few years later, a new species, Glomus epigaea, was described from spore masses produced on plants in the same greenhouses (Daniels \& Trappe, 1979). This species was erroneously synonymised with $G$. versiforme, but later study showed that these two organisms were not conspecific, and also G. epigaea was renamed as above. 


\section{AMF AT THE ROYAL BOTANIC GARDEN EDINBURGH}

Most species of AMF are completely subterranean, their spores being produced singly or in loose clusters in or around the roots of their hosts. Special techniques are needed to locate and extract such spores (Walker et al., 1982). However, some species produce sporocarps or large clusters of spores on the substrate surface. My attention was drawn to some of these associated with potted plants in the research greenhouses at RBGE by R. Watling in May 1980. Since then I have been intermittently collecting specimens from these greenhouses (see Appendix 1 for a list of AM and host plant species), and have collected specimens from the following host species:

Aeschynanthus buxifolius

Araucaria biramulata

Araucaria laubenfelsii

Araucaria scopulorum

Blechnum palmiforme

Calochlaena sp.

Cephalotaxus wilsoniana

Cibotium schiedei

Cryptomeria japonica

Cunninghamia konishii

Cunninghamia lanceolata

Cyathea sp.

Cyathea spinulosa

Dacrycarpus imbricatus

Dicksonia blumei

Diplazium proliferum

Falcatifolium taxoides
Glyptostrobus pensilis

Gossypium tomentosum

Libocedrus plumosus

Lophosoria quadripinnata (Fig. 3)

Metasequoia glyptostroboides

Papuacedrus papuana var. arfakensis

Phyllocladus trichomanoides

Podocarpus polystachyus

Podocarpus rubens

Retrophyllum rospigliosi

Ruizia cordata

Streptocarpus venosus

Taxodium distichum

Thyrsopteris elegans

Woodwardia orientalis var. prolifera

(with Oxalis as a weed)

Zingiber sp.

Other specimens were found among unidentified tree ferns and conifers, and fruiting on the gravel in mature gravel beds occupied by large potted plants and self-sown ferns.

Giving species names to the specimens from the greenhouses is difficult. Recent work on phylogeny, based largely on sequence analysis of the rRNA gene, has shown that determining species of AMF from morphological characteristics alone is prone to errors. Many of the species already named were described only from field-collected specimens without any knowledge of their biology. Often such specimens contain only dead spores, and small differences in spore morphology that were used to separate species may have been misleading, resulting in synonymy. Secondly, the production of sporocarps or spore masses was used as one of the main morphological characteristics used to separate species, but molecular evidence has shown that this habit occurs in very widely separated species, some of which are even in different families, and also 
that some species with epigeous spore clusters also produce individual spores in the soil that are different morphologically, and thus might be described as separate species. In addition, some species of AMF with similar spore morphologies have turned out to belong to separate families and orders of the Glomeromycota (see Krüger et al., 2012). It has not yet been possible to carry out the necessary molecular investigation on the specimens collected to date from RBGE, but preliminary identification has shown that there are at least four different species producing epigeous sporocarps or spore masses. Three species can be identified with a high degree of certainty: Diversispora epigaea, Sclerocystis coremioides (which may be synonymous with $S$. dussii) and Rhizophagus fasciculatus. Three other species, Glomus flavisporum, G. cerebriforme and G. pallidum are in need of verification. At least two others might be species new to science, and have been established in culture with Plantago lanceolata as a host plant. They await molecular and full morphological characterisation before they can either be confirmed as undescribed, or given an existing species name.

Apart from collections at RBGE, specimens of a sporocarpic species were also collected from a potted Dicksonia antarctica in a greenhouse at the Botanischer Garten, Jena, Germany by Dr A. Gminder. This fungus has not as yet been identified. Although not in a botanic garden setting, spore masses of $D$. epigaea have also been found on a potted Wollemi pine (Wollemia nobilis) in a retail outlet at Westonbirt Arboretum, and on the surface of the substrate in which a Dracena sp. was growing as a houseplant. Another mass of spores was found on a potted Choisya ternata in a commercial nursery, and a spore from this was used to establish a pot-cultured isolate. All of these sporocarps or spore masses were produced on potted plants in highly organic substrates, though whether the organic nature has any relevance is not known - it may merely be coincidence that plants in these situations are normally potted up in highly organic substrates and maintained for sufficiently long for sporulation to take place. Certainly the fungus from the Choisya later formed spore masses with Plantago lanceolata potted in a mixture of sand and clay.

It is impossible to say anything about the true geographic origins of these fungi. They might have been imported as mycorrhizas on rooted plants, but they occur also on plants from cuttings, spores and seeds, and may well have already been present in the substrate, or have transferred through contact with AMF already occupying the gravel on the benches or the nursery environment.

\section{BOTANIC GARDEN GLASSHOUSES AS ECOSYSTEMS}

Collecting AMF in glasshouses is most rewarding when the beds are 'mature' and have become a relatively stable ecosystem. Older plants produce more sporocarps, and beds with roots ramifying through them from existing pots can act as a reservoir for AMF that can then make contact with roots through the drainage holes. Benches covered by membranes on which the pots are separated from each other may restrict the development of such systems, and consequently if AMF are considered desirable, 
they will have to be introduced artificially. Not all AMF produce sporocarps or spore masses. Indeed, the majority of species appear to produce their spores exclusively in the substrate or in the roots of their hosts. Such species can be discovered only by special sampling techniques, including clearing roots with potassium hydroxide $(\mathrm{KOH})$ and bleach or extracting spores with sieving or centrifugation methods.

\section{THE ROLE OF AMF}

The fungi, most of which cannot grow saprobically (that is, they cannot obtain carbon directly through breakdown of organic matter), obtain their carbohydrates from the plant host. The main benefit to the hosts is in nutrient uptake, especially in the supply of phosphorous, which is absorbed in the form of poorly mobile but essential phosphate compounds. The fungi are able to access phosphate more readily, largely because of their ability to produce large amounts of exploratory mycelium in the soil. The fine threads of mycelium thus bypass the P-depletion zone that forms around roots. The phosphate is then passed on to the host plant in exchange for carbohydrates. There are considered to be other benefits to the plant such as enhancement of drought tolerance, and possible increase in resistance against root pathogens, but these are less well documented than the nutrient advantages (Smith \& Read, 2008).

The potential benefits have resulted in the production of numerous commercial products containing AM fungi that are marketed as beneficial to the establishment and growth of plants. The use of an internet search engine with 'mycorrhiza inoculum' as a search term will produce several competing sales pitches. Consequently, the question might be raised as to whether or not manipulation of AMF would be worth considering for routine production and maintenance of the valuable plant germplasm found in botanic gardens (particularly in 'clean' systems where pots are maintained so there is no possibility of cross-colonisation through root or mycelial contact). It is clear from the collections already mentioned that where such contact is possible, at least some species of AMF can establish themselves without the assistance of 'human resources' (as personnel departments like to call their staff these days), but we know so little about the special situation of potted plants in greenhouse collections or rare plants transplanted to soil in the garden that it is not possible to provide science-based guidance. It is recommended that any commercially obtained inoculum be tested initially by comparison with both previous normal practice and with plants treated with inoculum that has been killed (e.g. by heating) to establish if the claims on the packaging are achievable in reality. Indeed, before embarking on large-scale inoculations, it may be advisable to approach an independent expert for an assessment of the product.

Although there is a general feeling that introduction of alien AMF in inoculum, commercial or otherwise, is likely only to be beneficial, information is lacking on the competitive effects on local AMF, and perhaps thought should be given to the potential danger of introducing fungi that might out-compete local species and act as invaders. There seems to be no published work on this aspect of introduced mycorrhizal fungi, 


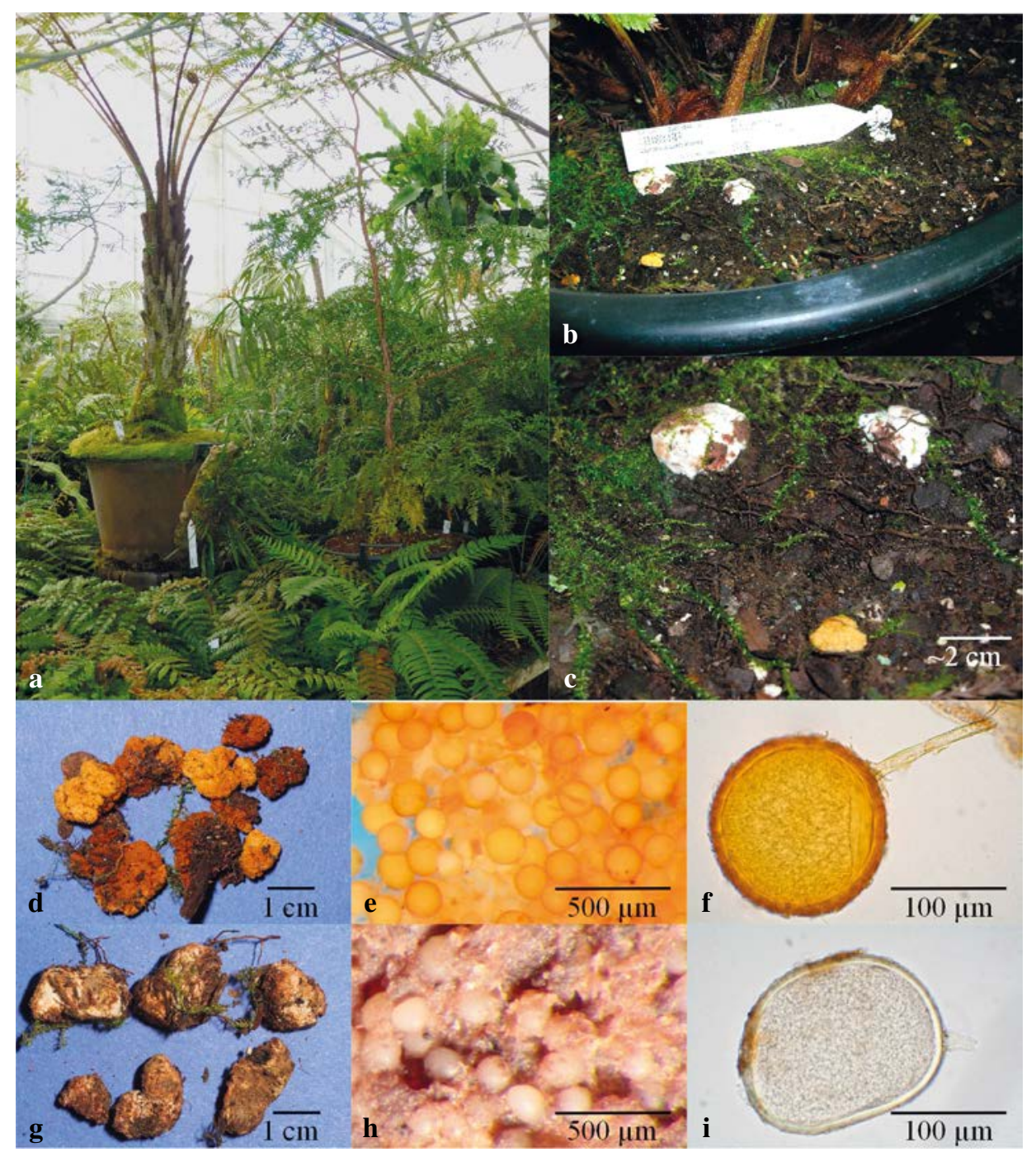

Fig. 4 Arbuscular mycorrhizal fungi from a tree fern in Glasshouse 26, RBGE (a) Mature glasshouse bed with both potted plants and the development of an ecosystem from 'volunteer' plants and spread of roots into the grit substrate (b) Substrate surface showing two different arbuscular mycorrhizal fungi producing sporocarps and spore masses (c) closer view of the two whitish sporocarps and a yellow spore mass (d) Collection of yellow to orange spore masses of Diversispora epigaea from the substrate surface or emerging from the pot's drainage holes (e) Surface of D. epigaea spore mass showing 'naked' spores (f) single spore of D. epigaea (g) Sporocarps of an undescribed AMF, probably a Diversispora sp., with a peridium enclosing the spores embedded in glebal hyphae $(\mathrm{h})$ section through sporocarp showing spores and gleba (i) individual spore dissected from the sporocarp in (h). Photos: C. Walker. 
but a recent paper (Sýkorová et al., 2012) offers a method based on DNA analysis for tracing specific cultures of AMF, thus providing a way of identifying them in the field. With methods such as this, it should be possible to assess whether or not introduced AMF are becoming dominant within an ecosystem.

Nevertheless, it would be well worth carrying out some research to establish if the theoretical potential benefits can be achieved through the introduction of AMF. For example, establishment of some exotic fern species is difficult, particularly after potting on of the immature sporophyte to individual pots; this has particularly been noted in some members of the family Culcitaceae, for example Culcita macrocarpa (A. Ensoll, RBGE, pers. comm.). Could the introduction of one or more AMF species result in better success? Would the addition of suitable mycorrhizal partners to broadleaved or conifer seedlings enhance their establishment, survival or success either in glasshouses or outside in the garden? Small-scale trials would not be difficult, but the choice of inoculum may be important. Commercial products are said to contain more than one fungus, but these might not be particularly well adapted to the conditions in botanic gardens. The species found fruiting already, such as those listed above, clearly are adapted to conditions in the glasshouses, but it remains unknown if the adaptation is balanced. Perhaps the fungi are particularly well served by the botanic garden ecosystem, but whether or not the host plants receive any major benefit remains unknown because they are as yet untested under such conditions. Nevertheless, one of them, D. epigaea, has been shown to confer advantages many times (e.g. under its former name Glomus epigaeum with Ginkgo biloba (Fontana, 1985) or citrus (Bi \& Kuo, 1990)) and under its often-used incorrect former name, Glomus versiforme (e.g. in eliciting a defence response against root knot nematode (Li et al., 2006), or enhancing growth of Asparagus officinalis seedlings (Hussey et al., 1984)).

Other than purchasing commercially available AMF products, there are three ways, each increasingly rigorous, of obtaining AMF for use in replicated trials. The first, and simplest, is to take cores of the substrate from pots in which mycorrhizas are already established, such as the fern illustrated in Fig. 4A. The substrate is roughly chopped and added to the new, sterilised substrate in the new pots. The mycorrhizas should then establish themselves as the roots of the new plants grow. This has the disadvantages not only of being an 'unknown quantity' in terms of fungal species, but also of the danger of introducing pests and pathogens such as nematodes, springtails, mites or non-AM fungi. The second method is to take spores, either extracted from the substrate of an existing established mycorrhizal plant, or from sporocarps or spore masses such as those in Fig. 4. This is more satisfactory in regard to fungal species, though it should be noted that more than one AMF can be cultured from such propagules, either because more than one species is sporulating in the same cluster of spores, or because non-sporulating (or hypogeously sporulating) species may be present as hyphae intertwined with the spores. For example, one culture established with spores from a spore mass of D. epigaea from RBGE failed to produce mycorrhizas with that species, but instead resulted in a culture of Paraglomus brasilianum, a different AMF. Multiple spore inoculum is also 


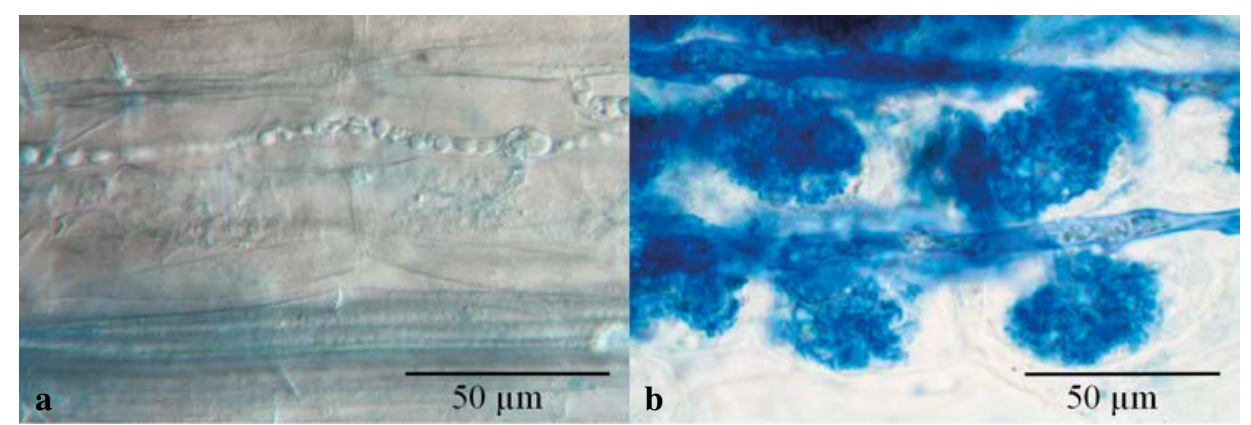

Fig. 5 Mycorrhizas, cleared in $\mathrm{KOH}$ and stained with blue ink, with Plantago lanceolata formed by arbuscular mycorrhizal fungi isolated from RBGE (a) Very weakly stained arbuscule with an undescribed species of Diversispora (b) Heavily stained arbuscules formed by a species of Sclerocystis. Staining characteristics may be of taxonomic or systematic relevance. Photos: C. Walker.

not immune from carrying pests and diseases. The third, and most satisfactory, is to establish pure pot cultures, preferably from single spores (Fig. 5), that can then be used to provide inoculum after a suitable period of growth (usually about three months). Whichever method is used, suitable controls should also be established (either simply with uninoculated substrate, or with inoculum killed in some way).

The discoveries reported here are interesting as records of the species in their own right, but we cannot say if the presence of mycorrhizas is actually benefiting the plants, except by analogy. It would be a good idea to carry out controlled experiments with and without these fungi to discover if there are positive benefits. To this end, some of the specimens from my collections at RBGE have been used to establish isolates with suitable hosts in sealed systems, and they are now available for scientific trials. They are also invaluable germplasm for much needed taxonomic and phylogenetic studies, should funds be available for their use. Botanic garden glasshouses can evidently act as an accidental repository for species of AMF that are not normally found in outdoor ecosystems, except perhaps in tropical environments, and though it may not be the primary role of such institutions, they can be considered as important to the subject of mycology as plants are to botany. If readers discover mycorrhizal fungi amongst their collections of plants, perhaps they might think of contacting an appropriate mycologist with a view to identifying and possibly isolating and conserving the fungi concerned.

\section{REFERENCES}

BI, K.C. \& KUO, S.C. (1990) VA mycorrhizae of citrus seedlings inoculated with Glomus epigaeum and its growth effects. Agriculture Ecosystems and Environment, 29, 35-38.

BRUNDRETT, M.C. (2009). Mycorrhizal associations and other means of nutrition of vascular plants: understanding the global diversity of host plants by resolving conflicting information and developing reliable means of diagnosis. Plant and Soil, 320, 37-77. doi:10.1007/ s11104-008-9877-9 
DANIELS, B.A. \& TRAPPE, J.M. (1979). Glomus epigaeus sp. nov., a useful fungus for vesicular-arbuscular mycorrhizal research. Canadian Journal of Botany, 57(5), 539-542.

DOTZLER, N., WALKER, C., KRINGS, M., HASS, H., KERP, H., TAYLOR, T.N. \& AGERER, R. (2009). Acaulosporoid glomeromycotan spores with a germination shield from the 400-million-year-old Rhynie chert. Mycological Progress, 8(1), 9-18. doi:10.1007/s11557008-0573-1

FONTANA, A. (1985). Vesicular-arbuscular mycorrhizas of Ginkgo biloba L. in natural and field controlled conditions. New Phytologist, 99, 441-447.

GERDEMANN, J.W. \& TRAPPE, J.M. (1974). The Endogonaceae in the Pacific Northwest. Mycologia Memoir, 5, 1-76. Published by the New York Botanical Garden in collaboration with the Mycological Society of America (Bronx, NY).

HELGASON, T., DANIELL, T.J., HUSBAND, R., FITTER, A.H. \& YOUNG, J.P.W. (1998). Ploughing up the wood-wide web? Nature, 394, 431.

HUSSEY, R.B., PETERSON, R.L. \& TIESSEN, H. (1984). Interactions between vesicular arbuscular mycorrhizal fungi and asparagus. Plant \& Soil, 79, 403-416.

KARSTEN, P.A. (1884). Fragmentia mycological XII. Hedwigia, 23, 39-40.

KRÜGER, M., KRÜGER, C., WALKER, C., STOCKINGER, H. \& SCHÜßLER, A. (2012). Phylogenetic reference data for systematics and phylotaxonomy of arbuscular mycorrhizal fungi from phylum to species level. New Phytologist, 193, 970-984. doi:10.1111/j.14698137.2011.03962.x

KRÜGER, M, WALKER, C. \& SCHÜßLER, A. (2011). Acaulospora brasiliensis comb. nov. and Acaulospora alpina (Glomeromycota) from upland Scotland: morphology, molecular phylogeny and DNA-based detection in roots. Mycorrhiza, 21, 577-587.

LI, H.-Y., YANG, G.-D., SHU, H.-R., YANG, Y.-T., YE, B.-X., NISHIDA, I. \& ZHENG, C.-C. (2006). Colonization by the arbuscular mycorrhizal fungus Glomus versiforme induces a defense response against the root-knot nematode Meloidogyne incognita in the grapevine (Vitis amurensis Rupr.), which includes transcriptional activation of the class III chitin. Plant \& Cell Physiology, 47(1), 154-163. doi:10.1093/pcp/pci231

MOSSE, B. (1953). Fructifications associated with mycorrhizal strawberry roots. Nature, 171, 974.

REDECKER, D., SCHÜßLER, A., STOCKINGER, H., STÜRMER, S.L., MORTON, J.B. \& WALKER, C. (2013). An evidence-based consensus for the classification of arbuscular mycorrhizal fungi (Glomeromycota). Mycorrhiza, 23, 515-531. doi:10.1007/s00572-0130486-y Available at: http://link.springer.com/journal/572/23/7/page/1

SCHÜßLER, A., KRUEGER, M. \& WALKER, C. (2011). Revealing natural relationships among arbuscular mycorrhizal fungi: culture line BEG47 represents Diversispora epigaea, not Glomus versiforme. PLoS one 6: e23333. doi: 10.1371/journal.pone.0023333

SCHÜßLER, A. \& WALKER, C. (2010). The Glomeromycota. A Species List with New Families and New Genera. Published in December 2010 in libraries at the Royal Botanic Garden Edinburgh, the Royal Botanic Garden Kew, Botanische Staatssammlung Munich and Oregon State University. Electronic version freely available online at www.amf-phylogeny.com

SMITH, S.E. \& READ, D.J. (2008). Mycorrhizal Symbiosis, Academic Press, San Diego, CA. SÝKOROVÁ, Z., BÖRSTLER, B., ZVOLENSKÁ, S., FEHRER, J., GRYNDLER, M., 
VOSÁTKA, M. \& REDECKER, D. (2011). Long-term tracing of Rhizophagus irregularis isolate BEG140 inoculated on Phalaris arundinacea in a coal mine spoil bank, using mitochondrial large subunit rDNA markers. Mycorrhiza, 22, 69-80. doi:10.1007/s00572011-0375-1 Available at: http://link.springer.com/article/10.1007/s00572-011-0375-1

WALKER, C. (1985). Endogone lactiflua forming ectomycorrhizas with Pinus contorta. Transactions of the British Mycological Society, 84, 353-355.

WALKER, C. \& MCNABB, H.S. Jr. (1984). Mycorrhizal symbionts associated with hybrid poplars from Iowa, USA. European Journal of Forest Pathology, 14, 282-296.

WALKER, C., MIZE, C.W. \& MCNABB, H.S. Jr. (1982). Populations of endogonaceous fungi at two locations in central Iowa. Canadian Journal of Botany, 60, 2518-2529. 


\section{APPENDIX 1}

Species of arbuscular mycorrhizal fungi found in glasshouses at RBGE with voucher number from C. Walker's collection and host (when known). Plant number is the RBGE accession number.

Note: the species and generic concepts in the Glomeromycota are presently in flux pending further molecular characterisation, and it is probable that those listed as Glomus sp. belong in a different genus.

\begin{tabular}{|c|c|c|c|c|}
\hline Fungal species & $\begin{array}{l}\text { Voucher } \\
\text { number }\end{array}$ & $\begin{array}{l}\text { Collection } \\
\text { date }\end{array}$ & $\begin{array}{c}\text { Plant } \\
\text { number }\end{array}$ & $\begin{array}{c}\text { Plant species as recorded at } \\
\text { time of collection }\end{array}$ \\
\hline Diversispora cf. epigaea & W4602 & 1 Jun. 1984 & $842581 \mathrm{H}$ & Falcatifolium taxoides \\
\hline Diversispora (?) sp. & W5948 & 21 Nov. 2011 & unrecorded & Lophosoria quadripinnata \\
\hline Diversispora (?) sp. & W5950 & 21 Nov. 2011 & 20090901 & Calochlaena sp. \\
\hline Diversispora (?) sp. & W5992 & 6 Apr. 2012 & 19982247 & Streptocarpus venosus \\
\hline Diversispora cf. epigaea & W4564 & 11 Dec. 2003 & unrecorded & Tree fern \\
\hline Diversispora epigaea & W4538 & 1 Jun. 1984 & $842581 \mathrm{H}$ & Falcatifolium taxoides \\
\hline Diversispora epigaea & W4586 & 1 Jun. 1984 & $842581 \mathrm{H}$ & Falcatifolium taxoides \\
\hline Diversispora epigaea & W4603 & 8 Mar. 2004 & 981020123 & Phyllocladus trichomenoides \\
\hline Diversispora epigaea & W5269 & 27 Aug. 2007 & unrecorded & $\begin{array}{l}\text { No particular plant. Epigeous } \\
\text { on a grit particle. }\end{array}$ \\
\hline Diversispora epigaea & W5859 & 20 Jan. 2011 & unrecorded & Blechnum palmiforme \\
\hline Diversispora epigaea & W5946 & 21 Nov. 2011 & unrecorded & $\begin{array}{l}\text { No particular plant - on gravel } \\
\text { and moss around potted ferns }\end{array}$ \\
\hline Diversispora epigaea & W5947 & 21 Nov. 2011 & $20050462 \mathrm{~A}$ & Cibotium schiedei \\
\hline Diversispora epigaea & W5951 & 21 Nov. 2011 & 20100922 & Thyrsopteris elegans \\
\hline Diversispora epigaea & W5993 & 6 Apr. 2012 & unrecorded & Dicksonia blumei \\
\hline Diversispora epigaea & W6109 & 6 Apr. 2012 & unrecorded & Dicksonia blumei \\
\hline Diversispora epigaea & W6110 & 21 Nov. 2011 & $20050462 \mathrm{~A}$ & Cibotium schiedei \\
\hline Diversispora epigaea (?) & W5949 & 21 Nov. 2011 & unrecorded & Lophosoria quadripinnata \\
\hline Diversispora epigaea (?) & W5952 & 21 Nov. 2011 & 20100922 & Thyrsopteris elegans \\
\hline Endogone sp. & W5994 & 6 Apr. 2012 & 19982247 & Streptocarpus venosus \\
\hline Glomus cerebriforme & W5945 & 21 Nov. 2011 & 20010277 & Cyathea sp. \\
\hline Glomus cf. flavisporum & W1679 & 27 Jan. 1992 & unrecorded & Metasequoia glyptostroboides \\
\hline Glomus cf. flavisporum & W1680 & 16 Dec. 1991 & 19890995 & Metasequoia glyptostroboides \\
\hline Glomus cf. flavisporum & W1681 & 27 Dec. 1991 & 19851599 & Taxodium distichum \\
\hline Glomus cf. flavisporum & W1682 & 28 Feb. 1992 & 19682163 & $\begin{array}{l}\text { Papuacedrus papuana var. } \\
\text { arfakensis }\end{array}$ \\
\hline Glomus cf. flavisporum & W2012 & 7 Dec. 1994 & 19763865 & Cephalotaxus wilsoniana \\
\hline
\end{tabular}




\begin{tabular}{|c|c|c|c|c|}
\hline Fungal species & $\begin{array}{l}\text { Voucher } \\
\text { number }\end{array}$ & $\begin{array}{l}\text { Collection } \\
\text { date }\end{array}$ & $\begin{array}{c}\text { Plant } \\
\text { number }\end{array}$ & $\begin{array}{c}\text { Plant species as recorded at } \\
\text { time of collection }\end{array}$ \\
\hline Glomus cf. flavisporum & W2014 & 8 Dec. 1994 & 19925011 & Araucaria laubenfelsii \\
\hline Glomus cf. flavisporum & W2015 & 8 Dec. 1994 & 19860863 & Araucaria scopulorum \\
\hline Glomus cf. flavisporum & W2016 & 8 Dec. 1994 & 19881603 & Araucaria biramulata \\
\hline Glomus cf. flavisporum & W2017 & 8 Dec. 1994 & 19921300 & Glyptostrobus pensilis \\
\hline Glomus cf. flavisporum & W2018 & 8 Dec. 1994 & 19860869 & Podocarpus polystachyus \\
\hline Glomus cf. flavisporum & W2019 & 8 Dec. 1994 & 19913512 & Diplazium proliferum \\
\hline Glomus cf. flavisporum & W1576 & 3 Oct. 1991 & 19890995 & Metasequoia glyptostroboides \\
\hline Glomus pallidum & W190 & 6 May 1980 & unrecorded & Various conifers \\
\hline Glomus pallidum & W234 & 17 Jun. 1980 & unrecorded & Cunninghamia lanceolata \\
\hline Glomus pallidum & W235 & 17 Jun. 1980 & unrecorded & Cunninghamia konishii \\
\hline Glomus pallidum & W236 & 17 Jun. 1980 & unrecorded & Libocedrus plumosus \\
\hline Glomus pallidum & W237 & 17 Jun. 1980 & unrecorded & Glyptostrobus pensilis \\
\hline Glomus pallidum & W238 & 17 Jun. 1980 & unrecorded & Cryptomeria japonica \\
\hline Glomus pallidum & W1995 & 7 Dec. 1994 & 19912816 & Cyathea spinulosa \\
\hline Glomus sp. & W1996 & 7 Dec. 1994 & 19912816 & Cyathea spinulosa \\
\hline Glomus sp. & W2013 & 7 Dec. 1994 & 19881418 & Dacrycarpus imbricatus \\
\hline Glomus sp. & W4568 & 22 Jan. 2004 & 19933756 & $\begin{array}{l}\text { Woodwardia orientalis var. } \\
\text { prolifera (with Oxalis sp. \& } \\
\text { moss as sparse weeds) }\end{array}$ \\
\hline Glomus sp. & W4569 & 22 Jan. 2004 & 19933756 & $\begin{array}{l}\text { Woodwardia orientalis var. } \\
\text { prolifera (with Oxalis sp. \& } \\
\text { moss as sparse weeds) }\end{array}$ \\
\hline Glomus sp. & W4570 & 23 Jan. 2004 & 20001721 & Retrophyllum rospigliosi \\
\hline Glomus sp. & W4574 & 26 Jan. 2004 & 20001721 & Retrophyllum rospigliosi \\
\hline Glomus sp. & W4604 & 8 Mar. 2004 & unrecorded & Podocarpus rubens \\
\hline Rhizophagus fasciculatus & W4566 & 11 Dec. 2003 & unrecorded & Tree fern \\
\hline $\begin{array}{l}\text { Sclerocystis cf. } \\
\text { coremioides }\end{array}$ & W5607 & 27 Apr. 2009 & unrecorded & Aeschynanthus buxifolius \\
\hline $\begin{array}{l}\text { Sclerocystis cf. } \\
\text { coremioides }\end{array}$ & W3021 & 27 Apr. 2009 & 19881148 & Gossypium tomentosum \\
\hline $\begin{array}{l}\text { Sclerocystis cf. } \\
\text { coremioides }\end{array}$ & W4499 & 25 Aug. 2003 & 19892962 B & $\begin{array}{l}\text { Ruizia cordata and associated } \\
\text { ferns \& mosses }\end{array}$ \\
\hline $\begin{array}{l}\text { Sclerocystis cf. } \\
\text { coremioides }^{2}\end{array}$ & W6108 & 8 Nov. 2012 & $20100751 \mathrm{~A}$ & Zingiber sp. \\
\hline $\begin{array}{l}\text { Sclerocystis cf. } \\
\text { pubescens }\end{array}$ & W5991 & 6 Apr. 2012 & 19982247 & Streptocarpus venosus \\
\hline
\end{tabular}

2. Taxonomy follows Schüßler \& Walker (2010) and Redecker et al. (2013). 
